JELENA ANĐELKOVIĆ GRAŠAR

Institute of Archaeology

Belgrade, Serbia

E-mail: jelenandjelkovic@gmail.com

MILICA TAPAVIČKI-ILIĆ

Institute of Archaeology

Belgrade, Serbia

E-mail: mtapavic@sbb.rs

ANA GAVRILOVIĆ, KRISTINA

BONDŽULIĆ, MIRJANA ĐORĐEVIĆ

The Archaeological Student Club

Faculty of Philosophy, University of Belgrade

Belgrade, Serbia
Received: November $15^{\text {th }} 2021$

Accepted: November $20^{\text {th }} 2021$

Original research article

902:37(497.4)"2021"

COBISS.SR-ID 55221257

https://doi.org/10.18485/arhe_apn.2021.17.9

\title{
PATHS OF STORYTELLING FOCUSED ON ARCHAEOLOGY AND ITS OUTREACH POTENTIAL - CASE STUDY ROMAN GAMES IN PTUJ
}

\begin{abstract}
This paper presents an example of good practice in the case of (re)presenting and the popularisation of heritage in cooperation with the local community. In addition to this kind of cooperation, the Roman Games in Ptuj is an event of an international character, reuniting the Western Balkan countries, which additionally helps the presentation of heritage and knowledge exchange and experience based learning. Via various activities and workshops, archaeological knowledge and finds related to the Roman period were used as the basis for creating a story about the past. In such a case, storytelling was based upon scientific data, but one of the important topics in student workshops was the stereotypes set by popular culture about archaeology and archaeologists. Based on the conducted activities and workshops, and primarily on the experience from the Roman Games, the paper will discuss how the concept of public archaeology has changed over time and how effective it is to have both professional and local communities involved in order to create a better storytelling narrative about the past that is later shared with the general public.
\end{abstract}

KEYWORDS: STORYTELLING, ARCHAEOLOGY, KNOWLEDGE, LOCAL COMMUNITY, ROMAN EVERYDAY LIFE, HERITAGE PRACTICES.

\section{INTRODUCTION}

Aspects of storytelling comprehend the oral or written way of sharing our stories with others, not as chronicles of what has happened but with some deeper meaning (McAdams 1993). The meaning of the past can, thus, be both subjective and liable to the choice of the individual/storytelling creator. In such a way, archaeology as an academic discipline considering hard facts, rational argument and identifiable sources, and storytelling related to fiction and entertainment seem to be opposite to each other (Tapavički-Ilić, Anđelković Grašar 2020: 132.). However, archaeologists are trained to imagine the past like the most detailed video series depicting various things such as dietary habits, closer ani- 


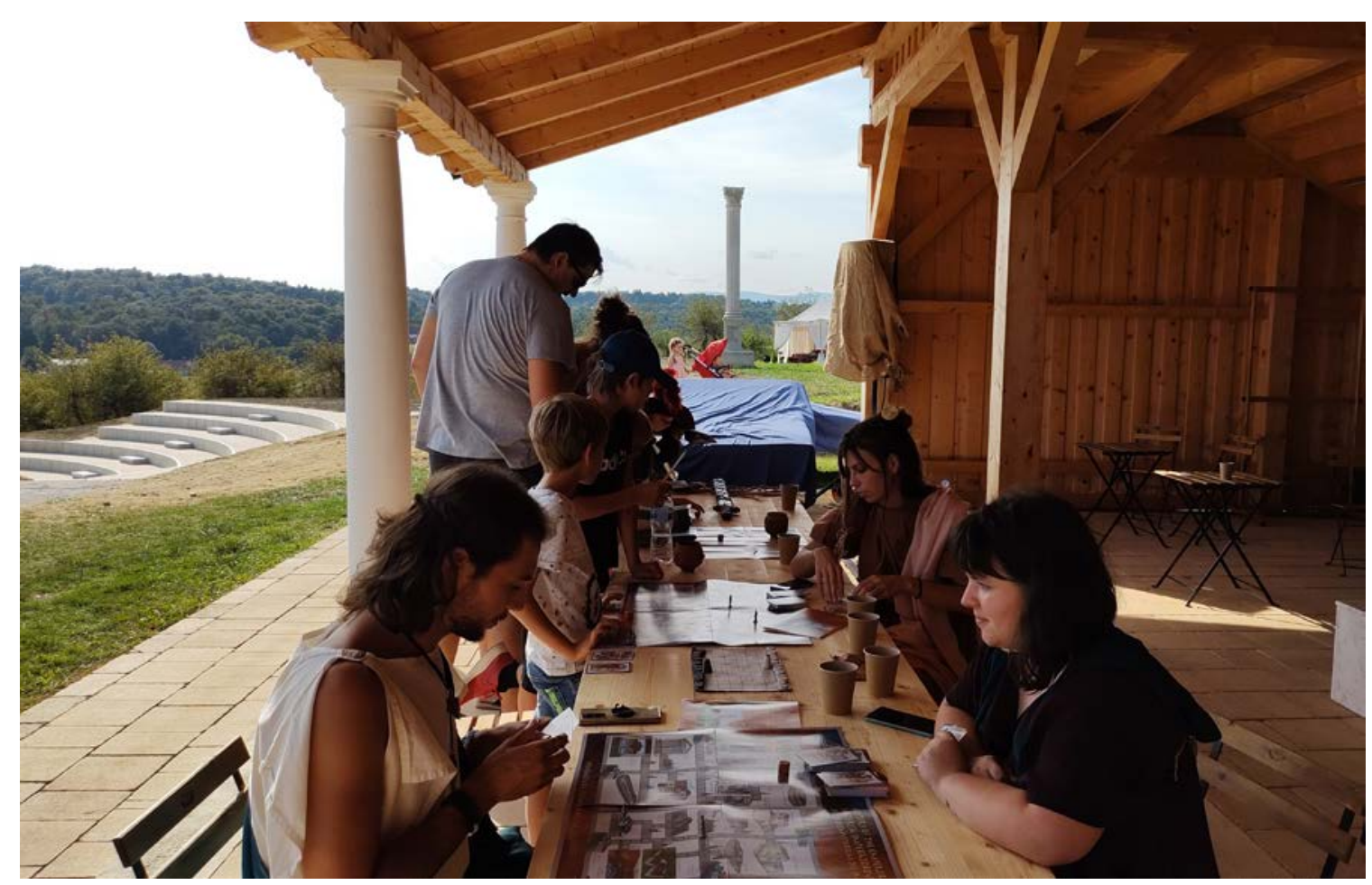

Fig. 1a. Workshop Gaming in practice - Board game.

mal-human relations, monetary systems, warfare techniques, treating the body of a loved one and many more aspects of human everyday life. On the other hand, postmodern society and a general disbelief in sciences have not bypassed archaeology as a discipline either. The epidemic of fake news, knowledge and different types of conspiracy theories that surrounds us daily is just one of the (side) effects the internet has brought us in the last two decades. With the strong pseudoscience ideas that are widespread within the general public, we are facing many problematic events and, simultaneously, the destruction of cultural heritage.

Happily, in the last few decades, science has overcome the traditional methods of (mostly using plain text and photos with the exception in museums or other institutionalised settings; and old, but gold, school documentary series and video materials) knowledge transmission between the scientific community and the general public. That is why new disciplines, such as public archaeology or community archaeology, research and evaluate the methods in which archaeologists work with the public, referring to archaeological work conducted by professionals, which includes, by design, the provision of participation opportunities for members of the general public or of a specific community (Moshenska 2017: 1-13; Thomas 2017: 14-30).

One of the effective ways for this archaeological knowledge sharing is the storytelling methodology, based upon scientific data - archaeological information. Storytelling is one tool to make the past accessible to the present and it combines fictional stories with factual archaeological research (Tapavički-Ilić, Anđelković Grašar 2020: 132). In such a way, storytelling can be a good educational tool, which is not going only in the direction from professionals to public, but vice versa as well - stories could push archaeologists to ask new questions - questions about the heritage that are important to current residents and not just the researchers (Praetzellis 2014: Janesko 2018). The trend of interactive storytelling in 


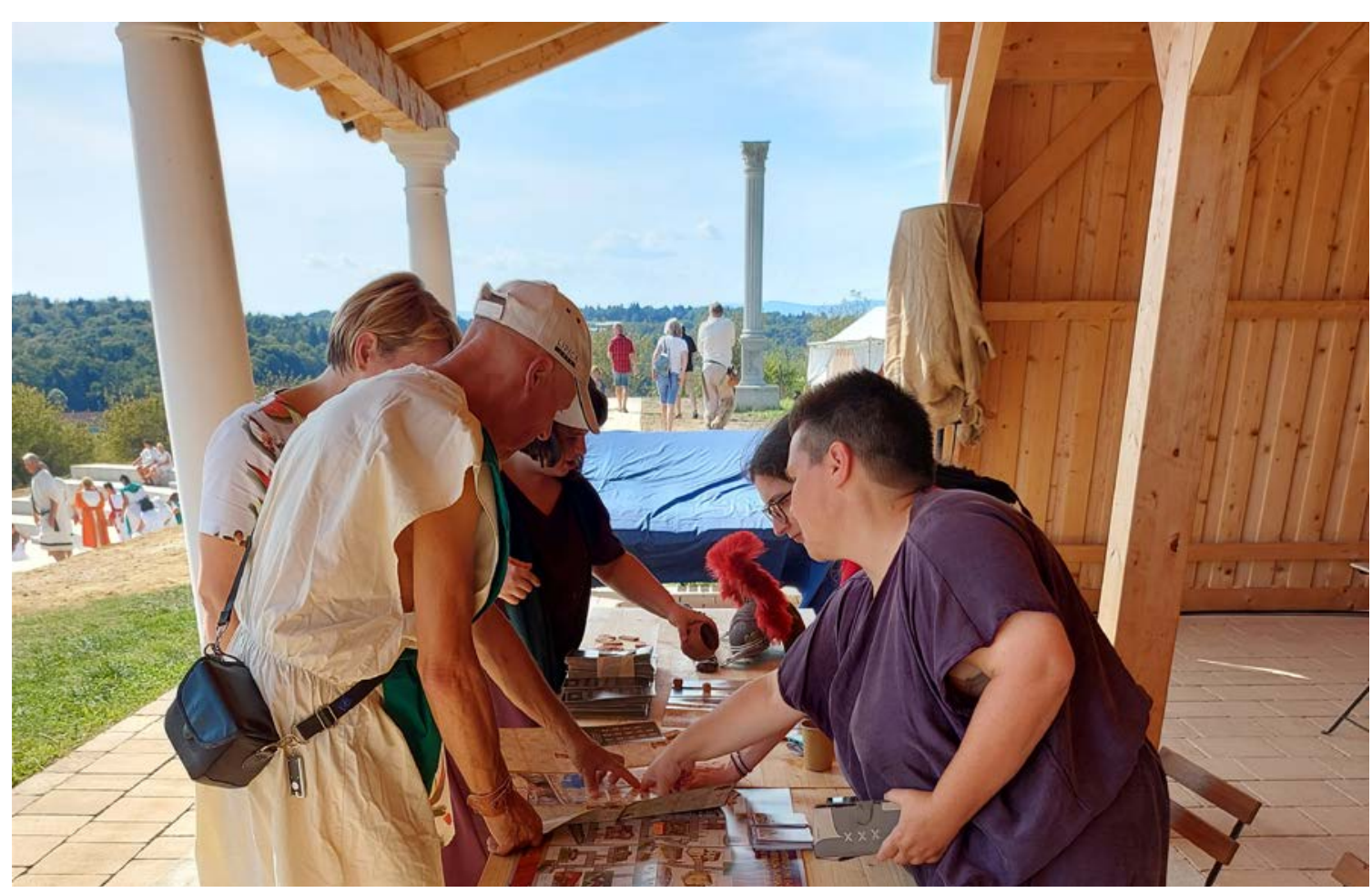

Fig. 1b. Workshop Gaming in practice - Board game.

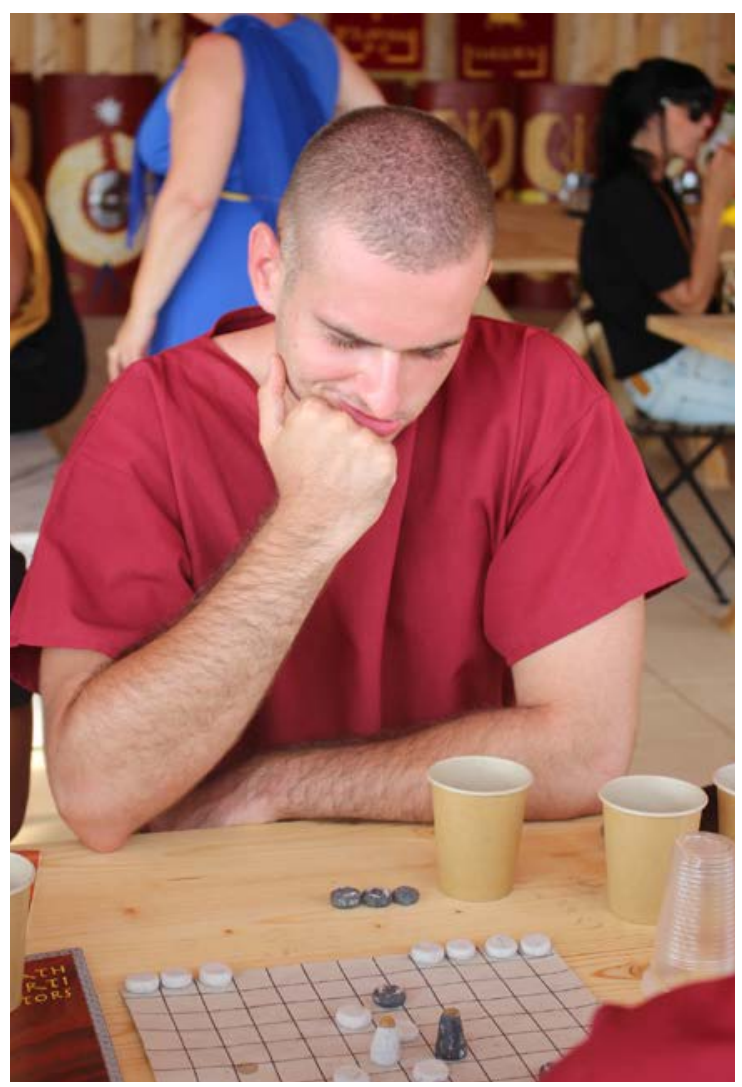

Fig. 1c. Workshop Gaming in practice - Board game. a cultural setting can be achieved through (video) games as well, which can essentially provide an experiential, entertaining and interactive relationship (Malegiannaki and Daradoumis 2017:1) that can be used as a tool for educational purposes. An eternally interesting thing to people was, is and will be the past, and even if we live in an age that is obsessed with technology, people still enjoy and engage mindfully in events that try to authentically depict a part of the past.

This can bring us to the conclusion that storytelling can be a powerful means of communicating all sorts of human truths, social values and community traditions to the wider public (Tapavički-Ilić, Anđelković Grašar 2020: 132). By combining archaeology and storytelling, a new form of communication can be created that brings together academics and audiences in a shared experience of the human past (Given 2009: 33).

Within the project "Sadike na prihodnost", co-funded by the European Commission's ERASMUS+ programme, partners the Society for Ro- 


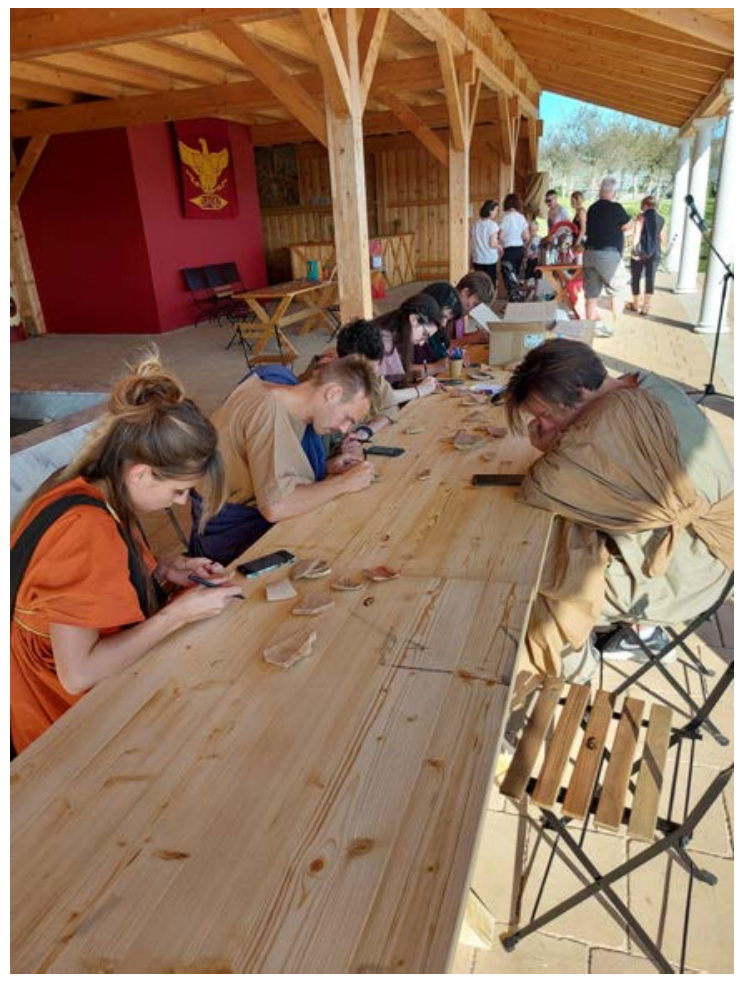

Fig 2a. Workshop Roman Ceramics: More than lifeless fragments/fortune from the past! man History and Culture (Društvo na rimsko zgodovino in kulturo Ptuj) and the Institute of Archaeology collaborated in the educational programme development and workshop design. The project included participation at the XIV Roman Games in Ptuj from $17^{\text {th }}$ to $22^{\text {nd }}$ of August, $2021 .^{1}$ The Institute of Archaeology, as a partner, invited students of archaeology (the Archaeological Student Club from the Faculty of Philosophy) to be involved in the creation of several workshops and the promotion of the ancient cultural heritage of Serbia. The festival is devoted to the ways of living during the Roman period and the heritage that overflows this city and region. It represents one of the rare examples showing how the local community can contribute and actively participate in the discourse about the past while learning about it and helping the local economy. The festival was a

1 About the Ptuj history in: Tušek 2019.

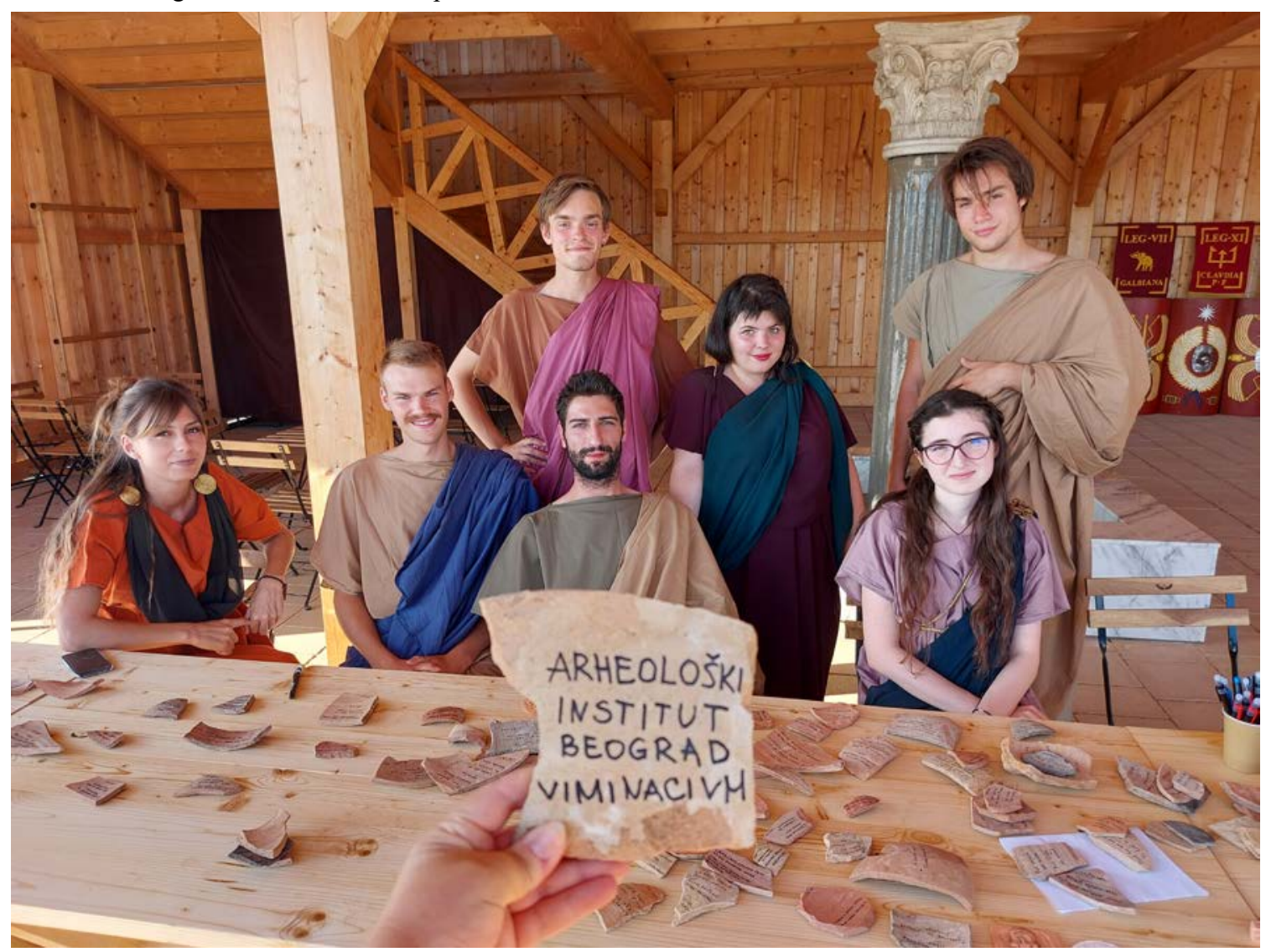

Fig 2b. Workshop Roman Ceramics: More than lifeless fragments/fortune from the past! 
good opportunity to meet with Slovenian colleges, as well as many other associations that participated in the realisation of all the festival activities. The first-hand experience of the past is the reason why such festivals have such a high attendance rate (by contrast, at most archaeological conferences you can not find more than a handful people from the general public) and can be used as opportunities to share science-based and new archaeological research methods with the general public.

\section{WORKSHOPS}

Workshops within the project "Sadike na prihodnost" were designed, developed and conducted by the Institute of Archaeology and the Archaeological Student Club from the Faculty of Philosophy with participation of students from

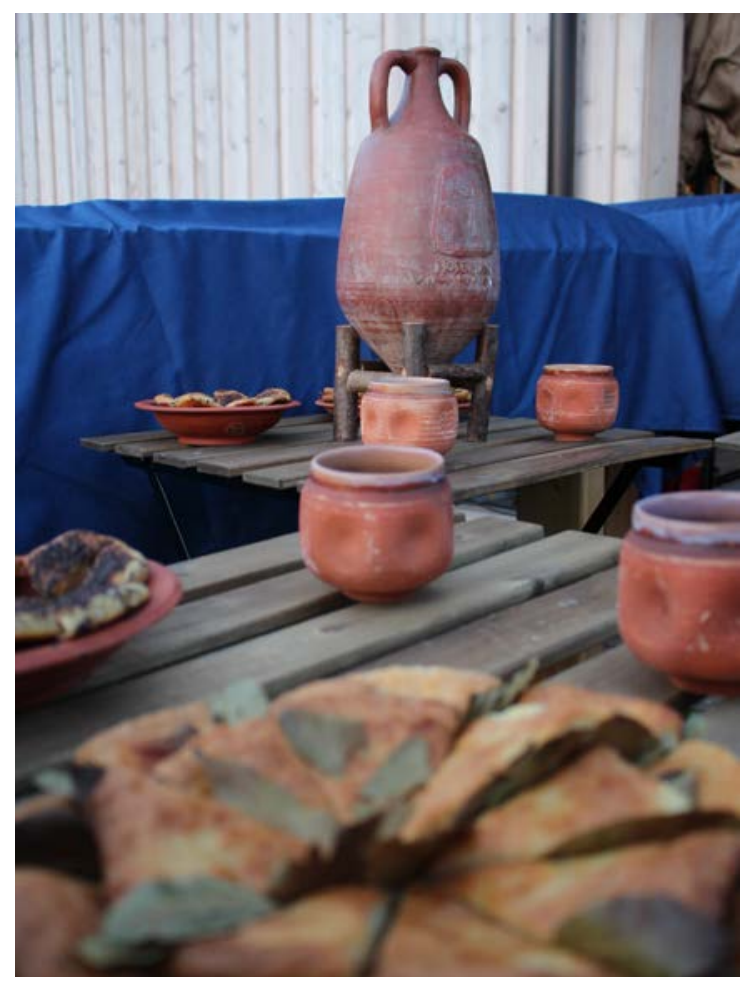

Fig. 3a. Workshop Roman food and dining in triclinium

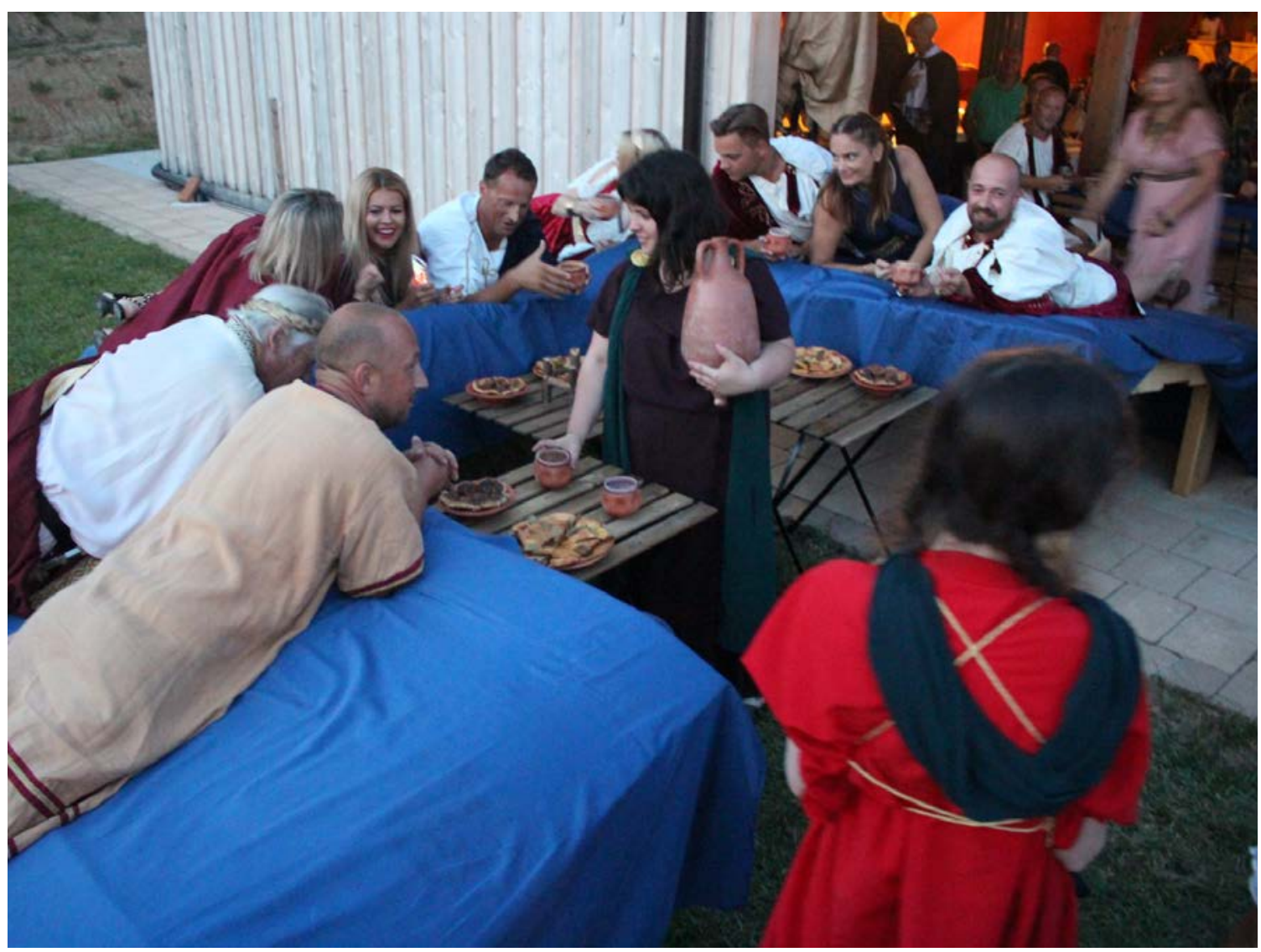

Fig. 3b. Workshop Roman food and dining in triclinium 
different class levels (from Bachelor to $\mathrm{PhD}$ programmes). Workshops were thematically divided between those with a more educational purpose and those that were oriented towards the general audience and the popularisation of archaeology as a science. Kristina Bondzulić, Ana Gavrilović and Mirjana Đorđević guided the second group, whose results will be presented in this paper.

\section{Archaeology beyond stereotypes of popular culture (Developed and led by Mirjana Đordević and Ana Gavrilović)}

As a result of the technological expansion through the end of the 20th century and the rise of creative industries, there are multiple virtual worlds that either simplify or fetishise certain aspects of disciplines such as archaeology. So far, the most complicated problem of stereotypical perceptions about archaeologists come from well known examples within popular culture like Indiana Jones, Lara Croft, World of Warcraft, Assassin's Creed, Conan the Barbarian, Asterix and Obelix (movies, games, graphic novels, etc.), and many many more.

The five key themes of the created picture about archaeologists in popular culture (according to Holtorf 2007) consider different and widespread misconceptions about archaeologists. Those five points describe the most obvious problem and that is- archaeologists are perceived as primarily adventurers and detectives, while making profound revelations about the past and taking care of ancient sites and finds (m)or(e like) destroying them.

Even though archaeology on screen has great characters and actors (Indiana Jones - the "daddy" of popular culture archaeology), women are also, although less often, portrayed as archaeologists. This is far removed from the current numbers of women and men employed in the field of studies and, hence, does not reflect the real internal dynamic of the archaeological community. As some of the most impressive examples of female archaeologists in fiction we single out, Dr Sydney Fox of "Relic Hunter", Vash of "Star Trek" and of course Lara Croft in Tomb Raider (Rakestraw, Reynolds 2001: 2), all of whom are important in the discussion about gender-related perceptions generated by popular culture.

Lara Croft is one example of how these women are portrayed. Even when the main character is a female archaeologist the hero and adventurer essence of general cinema (mis)conceptions are still reserved for men. When it comes to physical appearance, women are very often judged on the basis of their physical appearance and it appears that both the fictional and non-fictional worlds enjoy a Western standard of beauty (Holtfor 2007: 84). The sexual objectification of female bodies in popular culture is just one of the real-life patterns that are included in fictional worlds but a realistic perception of archaeology as a science and its knowledge is not. How the public as a passive consumer reacts to this and how it affects the observation of female archaeologists, since people already have a distorted image of archaeology as a profession, is one of the recently more discussed problems in the fields of archaeology and popular culture.

When it comes to the truly problematic perceptions of archaeologists, gender does not have an effective role. Like Indiana Jones, Sydney Fox, aka Relic Hunter, is a professor of archaeology and cultural anthropology, but at the same time she is presented as a treasure hunter. She is portrayed as a very intelligent person who, when she is not teaching at university, searches for stolen relics with the intention of returning them to their rightful owner or to a museum. One of the interesting facts about this series is that her assistant and companion on her adventures, Nigel, represents "weakened" European masculinity. Nigel's character in the series is very intelligent but extremely timid, so his fear of conflict highlights Sydney's qualities. (Derfoufi 2019: 11). The way in which these characters are presented is very interesting, so one can ask why the main character is 
not a man, but a woman to whom stereotypically masculine traits are attributed, while the assistant is presented as a timid person who might be considered a stereotypical image of a woman. Maybe it is a change of roles that should attract the audience, or the authors of this series wanted to break the stereotypical images imposed on us by society. It should be said that these types of perceptions of archaeologists, as relic hunters, can only cause a larger problem with illegal excavations and treasure hunters, especially when talking about countries that have a low level of conscience and knowledge about cultural heritage.

One of the important topics the workshop initiated with the audience was the potential of merging the gaming industry with the cultural knowledge that we have, for the purpose of meaningful and engaging learning about the past. In that sense, students talked about how "games concentrated (on and) for cultural heritage differ from other games for education because they additionally manage to preserve, reproduce and allow the appreciation of cultural content which can be intangible or tangible" (Malegiannaki and Daradoumis 2017:1).

In some cases, great monuments of our time (re)present a part of cultural heritage, as is the situation of Notre Dame cathedral in Paris. In one of the many episodes within the Assassin's Creed storyline, the time and place of the action and mission are set in the $15^{\text {th }}$ century in Paris, France. Following the most recent and devastating burning of this irreplaceable architectural piece in 2019, it came to the attention that one of the rare, and surprisingly very historically accurate 3D models of this monument exists in the previously mentioned games. In the context of heritage preservation and the different measures that it implies, we think it is important to emphasise the possibility of preserving cultural heritage through video games, as with the example of Notre Dame (Mochoki, 2021). These were the topics that the students actively engaged with the audience regarding how our favourite masterpieces of popular culture have shaped our perceptions of the real world we live in. Previous considerations indicate that video games have the potential to influence both players' perceptions of the past and their identities in the present, possibly to a much greater extent than through other, less interactive, encounters with the past. Crucial to the popularisation of archaeology in this way is the need for experts - archaeologists, to gain a better understanding of how to create and mediate the virtual past, which would lead to improved communication and knowledge of the past through virtual media and would democratise both the creation and experience of interactive views of the past.

Thus, we are facing a double-edged sword considering the popularisation of archaeology within projects that come from creative industries; on the one hand they are responsible for creating stereotypes about archaeologists and their beloved science of the past, while on the other hand they can be used as educational and outreach tools for overcoming our problem with the general public.

\section{Gaming in practice - Board games (led by Kristina Bondžulić and executed by the entire team $)^{2}$}

Just as entertainment and games are a significant part of human life today and a moment of relaxation, board games were part of everyday life in Roman times as well. During their free time, the Romans indulged in entertainment, and archaeological finds are helpful in the reconstruction of those games that bear great importance because they shed light on moments that belonged to all inhabitants of the empire, regardless of their status, profession or religious beliefs (Janković 2007: 28). Some of the board games that were played in the Roman era are still played today in numerous different physical and digital formats.

2 Jelena Anđelković Grašar, Milica Tapavički-Ilić, Mladen Mladenović, Danica Grujić, Kristina Bondzulić, Ana Gavrilović, Predrag Đerković, Mirjana Đorđević, Peđa Perić and Ivan Ilić. 
During the workshop (Fig 1a, b, c), students were able to exchange knowledge with the participants through two such games, while a third game was formerly made for the education and promotion of the archaeological site of Viminacium. ${ }^{3}$ In the workshop, models were made of Roman cubes, which were originally made of animal bones and placed in the graves of the deceased at Viminacium, and whose primary role was to predict fate were included (Biro 1994: 61). Tossing the dice at our stand and seeing what number they got was a fun way for visitors to determine how lucky they are.

In terms of chip-based games (board games), visitors got the opportunity to learn about Ludus Latrunculorum, a game that is similar to today's "Nine-man Morris, Mill, and or Mills". The primary idea behind the game is to surround your opponent with chips so that he cannot move across the board, therefore eliminating him from the game. The winner of the game is subsequently given the title of "Emperor" (Janković 2007: 31).

The story of the game "The Mystery of the Emperor's Death" begins in the year 251, when Emperor Hostilian, a young man, died in Viminacium. Although historical accounts indicate that he died of the plague, the circumstances surrounding his death still remain unclear. ${ }^{4}$ Following this introduction, the players set out to solve the mystery by moving across the fields on the board, gathering information from the inhabitants of the ancient city, falling into the hands of the Roman police, and visiting various buildings explored within the site, which also provide information. Visitors took on the role of detectives, and several of them became so engrossed in the game that they stayed behind our counter for hours. With the collaboration and assistance of their parents

3 The game's name is Mystery of the Emperor's death and its creator is the archaeologist Nemanja Mrđić PhD in: Mrđić 2012, 126; Anđelković Grašar, Rogić, Nikolić 2013, 12.

4 Inspiration for the game's twist is taken from the storytelling developed for the interpretation of Viminacium, in: Mrđić 2012, 126. (who learned Serbian during the time of Yugoslavia), this fantastic team was able to overcome the language barrier with the younger population. We subsequently gave copies of the "Mystery of the Emperor's Death" to the most interested children so that they could enjoy the game at home, with friends who did not attend the Roman Games.

\section{Roman Ceramics: More than lifeless fragments, a fortune from the past! - (Executed by the entire team ${ }^{5}$ )}

Since the beginning of archaeology, ceramics have been identified as a type of archaeological find that is chronologically sensitive and, hence, valuable for dating, construction of relative-chronological schemes, and the consideration of status affiliation, migration, or spread of cultural influences (Orton \& Huges 2013: 4; Vuković 2017: 686). At a site such as the ancient military camp and city of Viminacium, which is being excavated throughout the whole year, in the course of only one day of excavation, several enormous bags of ceramics can be discovered. Of the previously and detailed processed ceramic fragments that had been identified as a statistical surplus and were expendable, we were able to create unique fortune cookies. On those pieces of ceramics, during the workshop, students inscribed Latin quotations with English translations (Fig. 2a, b), with the intention of creating a game called "What fortune does your past tell you?". ${ }^{6}$

Through this game, participants of the Roman Games were able to have fun by selecting a random piece of pottery from a vessel full of fragments, from which they read aloud what the past had to say about them. The game's meaning

5 Jelena Anđelković Grašar, Milica Tapavički-Ilić, Mladen Mladenović, Danica Grujić, Kristina Bondzulić, Ana Gavrilović, Predrag Đerković, Mirjana Đorđević, Peđa Perić and Ivan Ilić.

6 This is the "tool" usually used in the Viminacium presentation and interpretation, in: (Anđelković Grašar, Tapavički-Ilić 2014, 197). 
also alluded to the significance of unique and irreplaceable Roman-era archaeological finds, all in the name of having a good time and making science more accessible to the general public. The participants loved this game, especially because they could take their pieces home with them as a momento. As a result, the ceramic remnants without context have taken on new meaning in the modern age, and now they can be found in the homes of our friends as a reminder of Viminacium and friendships in Ptuj.

\section{Culina Romana - (executed by the entire team $^{7}$ )}

During the main day of the Festival, after the participants came back to the campus, the students, guided by experts from the Institute of Archaeology, started preparing a meal for the most important guests of the evening. A whole afternoon was spent in the kitchen, by the authentic Roman oven, heated by wood. Three meals were prepared according to the famous Apicius cookbook: libum, globi and savillum. ${ }^{8}$ All students were taught culinary skills and recipes, while the public enjoyed the unique spectacle.

The food was served in the triclinium $(3 a, b)$. In the Roman world, the triclinium was a dining room that consisted of three couches (Keddie 64). It is defined as a hierarchical space where the focus was on the wealth, status and power of the host (Gavrilović, Anđelković Grašar 2020: 282286). The triclinium, in the literal sense, consisted of three wide couches that were put in the shape of the Greek letter Pi. There was room on each couch

7 Jelena Anđelković Grašar, Milica Tapavički-Ilić, Mladen Mladenović, Danica Grujić, Kristina Bondzulić, Ana Gavrilović, Predrag Đerković, Mirjana Đorđević, Peđa Perić and Ivan Ilić.

8 Reconstruction of the famous Roman recipes are interpreted by archaeologist PhD Angelina Raičković Savić and adopted to regular Viminacium cuisine, while the most notable recipes are published as well, in: Korać, Raičković Savić 2014. for three people leaning on their left elbow and facing a central table attended by slaves (Keddie 67). The triclinium was visited by the most important guests of the Roman Games and, in addition, the food was served to the other visitors and participants. The food was served in ceramic vessels brought from Viminacium, and was accompanied by wine. The overall success of the meal was evident from the comments the team received and, therefore, this part of the games proved, once again, that Roman food never gets old!

An important part of the activities included a procession through the streets of Ptuj. During this walk, all participants in the Roman Games were dressed in Roman clothes and, as such, brought the city back to the past. This event was enthusiastically enjoyed by locals and tourists, and even some members of our team were a great inspiration to the photographers who came to record this event.

\section{CONCLUSION}

Sharing our research discoveries and knowledge about the past with the general public/local community is, or rather, should be one of the essentials of archaeological work. This festival is an fine example of good practice that has become an annual manifestation, encouraged and supported by the local community as well as the local authorities of Ptuj. Thanks to the members of the Ptuj Society for Roman History and Culture (Društvo za rimsko zgodovino in kulturo Ptuj), and the enormous engagement with and love towards the Roman past of its president Andrej Klasinc, a specific type of community archaeology has been spontaneously aroused in Ptuj. This can be considered an opportunity for the discipline, which can be enriched by seeing the archaeological remains in a new light and to think in new ways about how the past informs the present (Marshall 2002: 218).

In this paper our wish was to emphasise how important it is to collaborate and involve the local community within the whole discussion about 
public and community archaeology, festivals, workshops and activities that are based on a scientific approach in the creation of storytelling. Gathering local and regional experts as well as amateur associations makes this festival a very unique experience for both professionals and the general public alike. The general conclusion can be that manifestations such as this that include science based storytelling methods and a re-vitalisation of the past in this form are one of the solutions for overcoming the problems of communication and knowledge transmission between the scientific community and the general public.

\section{BIBLIOGRAPHY}

Anđelković-Grašar, J., Rogić, D., Nikolić, E. 2013

Viminacium, Archaeological Park - Modern Code for Re-Reading the Past of the Roman City and Legionary Camp, in Studies on Disasters, Catastrophes and the Ends of the World in Sources, Acta Archaeologica Pultuskiensia vol. IV, (ed.) J. Popielska-Grzybowska, J. Iwaszczuk, Pułtusk, 9-15.

Anđelković Grašar, J. Tapavički - Ilić, M. 2014 Senior Visitors, Junior Enthusiasm: Analysis, of visitors' questionnaire, Archaeology and

Science 9: 191-204.

\section{Biro, M. 1994}

The Bone Objects of the Roman Collection. Budapest: National Museum.

Gavrilović D., Anđelković Grašar J., 2020

Funeral Banquet, Procession or an Offering Scene - A Few Remarks on Roman Provincial Painting, Banatica 30/1: 271-296.

Derfoufi, M. 2019

Archaeology and the archaeologist on Screen. In: "Masters" and "Natives": Digging the Others' Past, (ed.) Gorshenina, S., Bornet, P., Fuchs, M. and Rapin, C., Berlin, Boston: De Gruyter, 255288.

\section{Given, M. 2009}

Archaeology and Storytelling: Encounters with the Past in Scotland and Cyprus, Historical Argyll 2009: 33-41.

\section{Holtorf, C. 2007}

Archaeology is a brand! The meaning of archaeology in contemporary popular culture, New York: Routledge.

\section{Janesko, S. 2018}

Archaeology in the Community, Interactive learning, Online discussion, Social Events: http:// www.archaeologyincommunity.com/historical-archaeology-and-storytelling/ (accessed Nov. 26th 2018).

\section{Janković, M. 2007}

Rimske igre na teritoriji Srbije, Antropologija, Petničkesveske 62 Valjevo: ISP: 28-33.

\section{Keddie G. Anthony. 2020}

Triclinium Trialectics: The Triclinium as Contested Space in Early Roman Palestine, Harvard Theological Review 113 (1): 63-88.

\section{Korać, M., Raičković Savić, A. 2014}

Culina Romana (Rimska kuhinja, Roman Cuisine), Beograd: Centar za nove tehnologije Viminacium, Arheološki institut: Beograd.

\section{Malegiannaki, I., Daradoumis, T. 2017}

Analyzing the educational design, use and effect of spatial games for cultural heritage: a Literature Review. Computers \& Education: 108.

\section{Marshall, Y. 2002}

What Is Community Archaeology? World Archaeology, Oct., 2002, Vol. 34, No. 2, Community Archaeology: 211-219. 
McAdams, D. P. 1997

The Stories We Live By. The Stories We Live By Personal Myths and the Making of the Self, New York: The Guilford Press (1993).

\section{Mochocki M. 2021}

Heritage Sites and Video-Games: Questions of Authenticity and Immersion, Games and culture vol.0: 1-27.

\section{Moshenska, G. 2017}

Introduction: Public Archaeology as Practice and Scholarship Where Archaeology Meets the World, in: Key Concepts in Public Archaeology, (ed.) Gabriel Moshenska, London: University College London Press, 1-13.

\section{Mrđić, N. 2012}

Roman cultural heritage as a tourist and educational resource, in: Archaeological Heritage: Methods of Education and Popularization, (eds.) Chowaniec, R. and Więckowski, W., BAR International Series 2443, Oxford 121-127.

\section{Orton, C., Huges, M. 2013}

Pottery in archaeology. Cambridge: Cambridge University Press.

\section{Praetzellis A. 2014}

Narrative and Storytelling for Archaeological Education in: Encyclopedia of Global Archaeology, Clare Smith (eds.), Springer New York, 51355138.

\section{Rakestraw, T., Reynolds, A. 2001}

Archaeology and the Public: Exploring Popular Misconceptions, Inquiry: The University of Arkansas Undergraduate Research Journal 2(1): 25-29.

Tapavički-Ilić, M. Anđelković Grašar, J. 2020

Storytelling. Is there a better method of archaeological site interpretation?, Proceedings From the 6th Scientific Conference Methodology and Archae- ometry, Zagreb 6-7 December 2018, (ed.) Ina Miloglav, Faculty of Humanities and Social Sciences, University of Zagreb, Zagreb 2020, 125 - 133.

\section{Thomas S. 2017}

Community archaeology, in: Key Concepts in Public Archaeology, (ed.) by G. Moshenska, London: University College London Press, 1-13.

\section{Tušek, I. 2019}

Rimska Vojska v Republiki in Cesarstvu ter Rimski Vojaški Nagrobniki iz Petovione, Ptuj: Zgodovinsko društvo "Poetovio 69".

\section{Vuković, J. 2017}

Keramičke studije i arheometrija: između analiza prirodnih nauka i arheološke interpretacije, Etnoantropološki problemi 12/3: 685-701.

\section{Links:}

http://viminacium.org.rs/arheoloski-park/programi-za-decu/edukativne-drustvene-igre/

http://viminacium.org.rs/arheoloski-park/programi-za-decu/

Arheologija i prirodne nauke (Archaeology and Science) is an Open Access Journal. All articles can be downloaded free of charge and used in accordance with the licence Creative Commons - Attribution-NonCommercial-NoDerivs 3.0 Serbia (https://creativecommons.org/licenses/bync-nd/3.0/rs/.

C̆asopis Arheologija i prirodne nauke je dostupan u režimu otvorenog pristupa. Članci objavljeni u časopisu mogu se besplatno preuzeti sa sajta i koristiti u skladu sa licencom Creative Commons - Autorstvo-Nekomercijalno-Bez prerada 3.0 Srbija (https://creativecommons.org/licenses/bync-nd/3.0/rs/. 
REZIME

RAZNOVRSNOSTI NARATIVA

BAZIRANIH NA ARHEOLOGIJI I POTENCIJAL ZA NJENO ŠIRENJE U JAVNOSTI - PRIMER

RIMSKE IGRE U PTUJU

KLJUČNE REČI: STORITELING/NARATIV, ARHEOLOGIJA, ZNANJE, LOKALNA ZAJEDNICA, RIMSKI SVAKODNEVNI ŽIVOT, PRAKSE U NASLEĐU.

Ovaj članak predstavlja primer festivala Rimske igre u Ptuju (Slovenija) kao dobru praksu popularizacije nasleđa, kroz saradnju sa lokalnom zajednicom. Ovo je događaj međunarodnog karaktera koji okuplja zemlje Zapadnog Balkana, što dodatno pomaže u prezentaciji nasleđa i razmeni znanja i iskustava na ovom prostoru. Kroz različite aktivnosti i radionice arheološka znanja i nalazi vezani za rimski period korišćeni su kao osnova za stvaranje narativa o prošlosti. Ovaj narativ razvijan je na naučnim podacima, a jedna od važnijih tema u studentskim radionicama bili su stereotipi koje postavlja popularna kultura o arheologiji i arheolozima. Radionice u okviru projekta "Sadike na prihodnost“ iz Erazmus + programa sufinansiranog od strane Evropske Komisije osmislili su, razvili i sproveli Arheološki institut i Klub studenata Arheologije Filozofskog fakulteta Univerziteta u Beogradu. Radionice su tematski bile podeljene na edukativne i one koje su bile posvećene široj publici i popularizaciju arheologije kao nauke.

Deljenje rezultata istraživanja i znanja o prošlosti sa širom javnošću jeste i trebalo bi da bude suština arheološke nauke. Festival Rimske igre u Ptuju postao je godišnja manifestacija koju podstiče i podržava lokalna zajednica, ali i lokalne vlasti Ptuja. Iz tog razloga ovim radom želeli smo da istaknemo koliko je važno sarađivati i uključiti lokalnu zajednicu u čitavu diskusiju o javnoj i društvenoj arheologiji, festivalima, radionicama i aktivnostima koje se zasnivaju na naučnom pristupu u kreiranju pripovedanja/narativa o prošlosti.
Okupljanje lokalnih i regionalnih stručnjaka kao i amaterskih udruženja čini ovaj festival jedinstvenim iskustvom kako za profesionalnu tako i za širu javnost. Opšti zaključak može biti da su ovakve manifestacije koje uključuju metode pripovedanja i revitalizaciju prošlosti u ovom obliku jedno od rešenja za prevazilaženje problema komunikacije i prenošenja znanja između naučne zajednice i šire javnosti.

\section{$* * *$}

Arheologija i prirodne nauke (Archaeology and Science) is an Open Access Journal. All articles can be downloaded free of charge and used in accordance with the licence Creative Commons - Attribution-NonCommercial-NoDerivs 3.0 Serbia (https://creativecommons.org/licenses/bync-nd/3.0/rs/.

Časopis Arheologija i prirodne nauke je dostupan u režimu otvorenog pristupa. Članci objavljeni u časopisu mogu se besplatno preuzeti sa sajta $i$ koristiti u skladu sa licencom Creative Commons - Autorstvo-Nekomercijalno-Bez prerada 3.0 Srbija (https://creativecommons.org/licenses/bync-nd/3.0/rs/. 